\title{
Perfect usage across languages
}

Henriëtte de Swart

\begin{abstract}
The PERFECT constitutes a puzzling category for typologists, historical linguists and formal semanticists alike. Is it a tense? Is it an aspect? Which grammatical forms qualify as PERFECTS? What is the core of the PERFECT meaning? This short paper suggests that progress can be made if we start using the wealth of digitized language data that has become available to uncover the semantics of the PERFECT through its contextual usages across languages.
\end{abstract}

Keywords: tense, aspect, perfect, cross-linguistic semantics

\section{$1 \quad$ Language data and linguistic theory}

An unparalleled amount of language data has become available over the past decade, but it is no easy matter to approach this material with appropriate linguistic research questions. If we learn to mine these data, we can develop linguistic theories that account for the ways in which the meanings encoded in language structure arise from language use in communication. This paper presents the beginning of a data driven case study in cross-linguistic semantics, namely the communicative usage of forms that look like PERFECTS.

\section{Features of the Present Perfect}

It is well known that the PERFECT displays rich cross-linguistic variation to the point that it has been characterized as a synchronically and diachronically unstable category (Lindstedt, 2000). The semantic core of the English Present Perfect is reference to an event that took place at some indefinite time in the past, the experience of which (1a) or the result state of which (1b) has current relevance (Portner, 2003; Ritz, 2012):
a. Mary has visited Paris. [experiential perfect]
b. Mary has moved to Paris. (she currently lives in Paris) [resultative perfect]

The characterization of the perfect as conveying a past event with current relevance also underlies its typological definition in Dahl and Velupillai (2013). According to Reichenbach (1947), the Simple Past and the Present Perfect both locate an event in the past, but differ in the perspective on the past event. The Present Perfect views the past event from the speech time, whereas the Simple Past shifts back to the past, and locates the reference time at the 
event time. This explains why the (British) English Present Perfect is incompatible with time adverbials with past time reference, as in (2a), and requires the use of the Simple Past, as in (2b):
a. $\quad *$ Susan has left yesterday.
Present Perfect
b. Susan left yesterday.
Simple Past
c. *Mary ha llegado ayer.
Pretérito Perfecto

(Spanish)

We find the same restriction on time adverbials in a language like Spanish (2c) (Schaden, 2009), but the examples in (3) illustrate that counterparts to the Present Perfect and the Simple Past both combine with time adverbials in Dutch (Boogaart, 1999; de Swart, 2007):
a.
Susan is om zes
Susan is at six
o'clock left
'Susan has left at six o'clock.'
$\begin{array}{llll}\text { b. Susan vertrok om zes } & \text { uur. } \\ \text { Susan left at six } & \text { o'clock }\end{array}$

uur vertrokken.

(Dutch)

(Voltooid Tegenwoordige Tijd)

(Onvoltooid Verleden Tijd)

We use small caps PAST, PRESENT and PERFECT to refer to the abstract form, independently of the language at hand. Along with variation in the distributional patterns of time adverbials, we find variation in PERFECT meaning. Example (4) illustrates the continuative reading of the Perfect:

Mary has lived in London for five years now.

Example (4) conveys that Mary moved to London five years ago, and is still living there now. The continuative reading is not always available in other languages. Linguistic variation in perfect meaning extends to the discourse level:
a. Als ich sie gestern getroffen habe, hat sie mich groß angesehen. (German)
b. $\quad$ When I met / *have met her yesterday, she looked / *has looked at me in a condescending way.

As observed by Löbner (2002) and de Swart (2007), German and French PERFECTS can be used to convey narrative progress, and indicate a sequence of events in configurations like (5a).

In line with Reichenbach's characterization of the PERFECT, the English Present Perfect is not used for narration (5b). Accordingly, it is not an anaphoric tense-aspect form, unlike the Simple Past (Partee, 1984). There is surprisingly little literature dealing with the discourse function of non-narrative, non-anaphoric tenses. Nishiyama and Koenig (2010) use Switchboard examples like (6) to argue that the English Present Perfect can be used to introduce a new topic:
A: Have you seen 'Dancing with wolves'?
B: Yeah, I've seen that, that was a really good movie.

The corpus example (6) shows how we can obtain new insights from naturalistic data. If we want to do that in a cross-linguistic perspective, we need to control the context to make sure PERFECT usage can be compared across languages. Translations constitute one possible strategy. 
In a good translation, the information from the source text is clearly and completely rendered in the target language. In de Swart (2007), I used Dutch, English and German translations of the French novel l'Etranger by Albert Camus, to investigate the translation problems raised by his choice to write the novel in an alternation of the Passé Composé (the French PRESENT PERFECT) and the Imparfait (the imperfective SIMPLE PAST). The translations confirm that French PERFECTS are felicitous with locating time adverbials in the past, but the English translator renders them in the Simple Past:

$$
\begin{aligned}
& \text { (...) ce n'est pas de ma faute si on a enterré maman hier au lieu d'aujourd'hui. } \\
& \text { But for one thing, it isn't my fault if they buried mother yesterday instead of today, (...) }
\end{aligned}
$$

(Camus, The Stranger)

We also observe that the narrative structure of sequences of French sentences in the Passé Composé leads to Simple Pasts in the English and Dutch translations:

Il est sorti, est revenu, a disposé des chaises. Sur l'une d'elles, il a empilé des tasses autour d'une cafetière.

He went in and out, arranging chairs. On one of them he stacked (PC) some cups round a coffee-pot.

(Camus, The Stranger)

So, the study of translations reveals important insights about cross-linguistic variation. It provides a way to empirically test claims that have been made in the theoretical literature on distributional patterns and restrictions on interpretations. It also reveals the distribution of labour between PRESENT PERFECT, SIMPLE PAST and SIMPLE PRESENT, as translators will switch to different forms to convey the meaning of the source language in the target language. So this means we don't need to study the PERFECT in isolation, but can study it in contrast to other tense-aspect forms that are available in the grammar. The competition-based approach is even more attractive when we place it in a multilingual setting.

\section{$4 \quad$ A plea for multilingual datasets}

From the examples in (7) and (8), we might infer that the English Present Perfect has a narrower distribution than its French counterpart. But (9) illustrates that the English Present Perfect has a wider distribution in other contexts:
a. Rien ne bouge.
(French)
(No et moi, Delphine de Vigan, 2007)
b. Nothing has moved. (English)
(No and me, translation, 2010)
c. Niets beweegt. (Dutch)
(No en ik, translation, 2007)

So far, we used translation data to compare PERFECTS in the source language, and check their translation in the target language. The triplet in (9) is the outcome of a different strategy whereby we search for PERFECTS in any language (source or translation) in a multilingual 
corpus. The English continuative PERFECT appears in the translation (9b), even though the French source text uses a SIMPLE PRESENT (9a), which the Dutch translator maintains in (9c). The comparison of multiple languages gives us a broader perspective on the competition between different tense-aspect forms, so there is a clear advantage to using multilingual datasets.

This strategy may lead us to stumble upon data that we weren't specifically looking for. For instance, we know that the resultative meaning constitutes the core of the perfect (cf. (1b)). But the example in (10) shows that it can also be conveyed by the English Simple Past:
a. In case you hadn't noticed, we just got a confession.
b. Falls es ihnen entging, er hat gestanden.
c. Si vous ne l'avez pas remarqué, on a des aveux.

(English original)

(German)

(French)

The triplet in (10a-c) appears in a multilingual corpus consisting of subtitles of television programmes and movies. It illustrates that the same temporal configuration can be conveyed by the SIMPLE PAST (10a), the PRESENT PERFECT (10b), or the SIMPLE PRESENT (10c). We classify (10b) as an instance of the resultative PERFECT, which is confirmed by the French translation that picks up on the result state only by using a SIMPLE PRESENT.

It may come as a surprise that the English Simple Past conveys a result in (10a), because this has been viewed as the core meaning of the Present Perfect (cf. (1b)). A formal criterion supporting the resultative flavor of the English Simple Past is its compatibility with the adverb already in example (11a) (from the internet):

(11) a. So I already bought my wedding dress. It's a Melissa Sweet Valentina. I bought it at only the second store I visited.

b. $\quad$ One in 10 single British women have already chosen their wedding dress (and one in 4 have already bought one).

There is an extensive literature on already, but in its temporal use, there is consensus that it is an aspectual operator that scopes over an imperfective sentence, that is, a state or an ongoing activity (Löbner, 1989; Mittwoch, 1993; Van der Auwera, 1993; Michaelis, 1996; Smessaert and ter Meulen, 2004). Under this analysis, de Swart (2013) argues that we expect English event denoting verb phrases to be compatible with already in the Past Progressive or the Present Perfect (as illustrated in (11b)), but not the Simple Past (11a). Such patterns are easily found, though, and confirm that the analysis of the PERFECT implies a many-to-many mapping between forms and meanings. That is, the same form (e.g., the English Present Perfect) can have different meanings, and the same meaning (e.g., result) can be conveyed by different forms.

\section{Conclusion}

In this short paper, I aimed to show that cross-linguistic semantics can benefit from taking into account naturalistic data that have become available on a large scale. More tools are becoming available for linguistics to search monolingual, parallel and multilingual corpora, and compositional semantics can benefit from these new developments to account for the negotiation of meaning in communicative contexts. Such an enterprise would suit Bożena Rozwadowska very well, I think. I greatly admire her work for its fine-grained empirical 
observations (especially on Polish) and their implications for linguistic theory. I hope these new data oriented approaches will help us to produce results that live up to her standards!

\section{References}

Boogaart, R. (1999). Aspect and temporal ordering. A contrastive analysis of Dutch and English. (Doctoral dissertation). Free University, Amsterdam.

Dahl, Ö. and Velupillai, V. (2013). The Perfect. In M. Dryer and M. Haspelmath (Eds.), The World Atlas of Language Structures Online. Leipzig: Max Planck Institute for Evolutionary Anthropology. (Available online at http://wals.info)

Lindstedt, J. (2000). The perfect - aspectual, temporal and evidential. In Ö. Dahl (Ed.), Tense and aspect in the languages of Europe (pp. 365-383). Berlin: De Gruyter.

Löbner, S. (1989). German schon - erst - noch: An integrated analysis. Linguistics and Philosophy, 12, 167-212.

Löbner, S. (2002). Is the German Perfekt a perfect perfect? In G. Katz, S. Reinhard, and P. Reuter (Eds.), Sinn \& Bedeutung VI. Proceedings of the Sixth Annual Meeting of the Gesellschaft für Semantik (pp. 255-273). Institute of Cognitive Science, University of Osnabrück.

Michaelis, L. A. (1996). On the use and meaning of already. Linguistics and Philosophy, 19, 77502.

Mittwoch, A. (1993). The relationship between schon/already and noch/still: A reply to Löbner. Natural Language Semantics, 2, 71-82.

Nishiyama, A. and Koenig, J. P. (2010). What is a perfect state? Language, 86, 611-646.

Partee, B. (1984). Nominal and temporal anaphora. Linguistics and Philosophy, 7, 243-286.

Portner, P. (2003). The (temporal) semantics and (modal) pragmatics of the perfect. Linguistics and Philosophy, 26, 459-510.

Reichenbach, H. (1947). Elements of symbolic logic. New York, London: The Free Press.

Ritz, M.-E. (2012). Perfect tense and aspect. In R. I. Binnick (Ed.), The Oxford handbook of tense and aspect (pp. 881-907). Oxford: Oxford University Press.

Schaden, G. (2009). Present perfects compete. Linguistics and Philosophy, 32, 115-141.

Smessaert, H. and ter Meulen, A. G. B. (2004). Temporal reasoning with aspectual adverbs. Linguistics and Philosophy, 27, 209-261.

de Swart, H. (2007). A cross-linguistic discourse analysis of the perfect. Journal of Pragmatics, 39, 2273-2307.

de Swart, H. (2013). Aspectual sensitivity of already. In M. Franke, F. Roelofsen, and K. Schulz (Eds.), Festschrift for Jeroen Groenendijk, Martin Stokhof and Frank Veltman, (pp. 241251). Amsterdam: ILLC.

van der Auwera, J. (1993). Already and still: Beyond duality. Linguistics and Philosophy, 16, 613653.

Henriëtte de Swart

Depertment of Languages, Literature and Communication

Utrecht University, Trans 10

3512 JK Utrecht, The Netherlands

e-mail: h.deswart@uu.nl 